\title{
Hematological convergence between Mesozoic marine reptiles (Sauropterygia) and extant aquatic amniotes elucidates diving adaptations in plesiosaurs
}

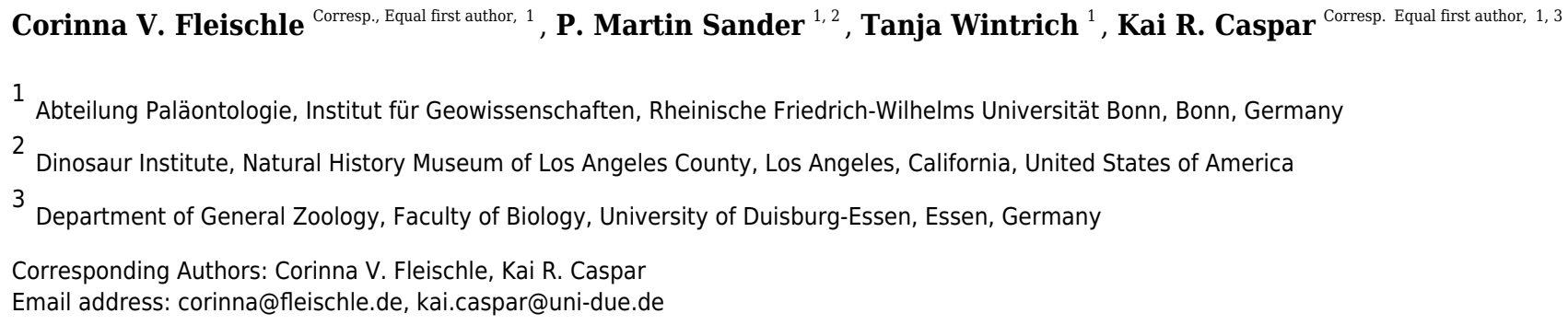

Plesiosaurs are a prominent group of Mesozoic marine reptiles, belonging to the more inclusive clades Pistosauroidea and Sauropterygia. The shift in habitat from shallow coastal waters in the ancestors of plesiosaurs to the open ocean were accompanied by profound changes in locomotion, sensory ecology and metabolism. However, investigations of physiological adaptations on the cellular level related to the pelagic lifestyle are lacking so far. Using vascular canal diameter, derived from osteohistological thin-sections, we show that inferred red blood cell size significantly increases in pistosauroids compared to more basal forms. This change appears to have occurred in conjunction with the dispersal to open marine environments, with cell size remaining consistently large in plesiosaurs. Enlarged red blood cells likely represent an adaptation of plesiosaurs for repeated deep dives in the pelagic habitat and mirror conditions found in extant marine mammals and birds. Our results emphasize physiological aspects of adaptive convergence among fossil and extant marine amniotes and add to our current understanding of plesiosaur evolution. 


\section{Hematological convergence between Mesozoic marine}

3 reptiles (Sauropterygia) and extant aquatic amniotes

4 elucidates diving adaptations in plesiosaurs

5

6

7 Corinna V. Fleischle ${ }^{1}$, P. Martin Sander ${ }^{1,2}$, Tanja Wintrich ${ }^{1}$, Kai R. Caspar ${ }^{1,3}$

8

$9 \quad{ }^{1}$ Abteilung Paläontologie, Institut für Geowissenschaften, Universität Bonn, Nussallee 8, 53115

10 Bonn, Germany.

112 Dinosaur Institute, Natural History Museum of Los Angeles County, 900 Exposition Boulevard,

12 Los Angeles, CA 90007, USA.

$13{ }^{3}$ Department of General Zoology, Faculty of Biology, University of Duisburg-Essen,

14 Universitätsstraße 5, 45117 Essen, Germany.

Corresponding Authors:

Kai R. Caspar

Email address: kai.caspar@uni-due.de

Corinna V. Fleischle

Email address: corinna@fleischle.de

\section{Abstract}

Plesiosaurs are a prominent group of Mesozoic marine reptiles, belonging to the more inclusive clades Pistosauroidea and Sauropterygia. The shift in habitat from shallow coastal waters in the ancestors of plesiosaurs to the open ocean were accompanied by profound changes in locomotion, sensory ecology and metabolism. However, investigations of physiological adaptations on the cellular level related to the pelagic 
30 lifestyle are lacking so far. Using vascular canal diameter, derived from osteohistological

31 thin-sections, we show that inferred red blood cell size significantly increases in

32 pistosauroids compared to more basal forms. This change appears to have occurred in

33 conjunction with the dispersal to open marine environments, with cell size remaining

34 consistently large in plesiosaurs. Enlarged red blood cells likely represent an adaptation

35 of plesiosaurs for repeated deep dives in the pelagic habitat and mirror conditions found

36 in extant marine mammals and birds. Our results emphasize physiological aspects of

37 adaptive convergence among fossil and extant marine amniotes and add to our current

38 understanding of plesiosaur evolution.

\section{Introduction}

41 The Sauropterygia arguably were the most successful clade of marine reptiles in the

42 Mesozoic era (Motani 2009, Kelley \& Pyenson 2015, Renesto \& Dalla Vecchia 2017).

43 The most speciose and long-lived taxon among sauropterygians were the

Eosauropterygia, which emerged in the Early Triassic (Rieppel, 2000; Benson et al., 2012, Jiang et al., 2014; Renesto \& Dalla Vecchia 2017). This clade traditionally comprises two major groups, the small-bodied Pachypleurosauria, whose monophyly is debated (Holmes et al., 2008; Klein, 2010), and the larger, morphologically more diverse Eusauropterygia (Rieppel, 2000) (Fig. 1). These, in turn, comprise the Nothosauroidea and Pistosauroidea. While the former went extinct before the end of the Triassic, the Pistosauroidea persisted until the K-Pg boundary (Rieppel, 2000; Ketchum \& Benson, 2010; Benson et al., 2012; Benson \& Druckenmiller, 2014). Pistosauroids are most prominently represented by the iconic Plesiosauria, the only sauropterygian group that survived the Triassic-Jurassic mass extinction (Benson et al., 2012; Wintrich et al., 2017) and continued to be highly successful throughout the Mesozoic. Apart from the plesiosaur radiation, pistosauroids include the basal paraphyletic non-plesiosaurian forms, herein referred to as "Pistosauridae". While pachypleurosaurs and nothosauroids inhabited shallow coastal waters, the more derived pistosauroids were largely pelagic animals, populating predominately offshore habitats (Sues, 1987; Krahl et al., 2013). This transition from coastal to pelagic ecosystems is widely acknowledged as an important event in sauropterygian evolution 
61 (e.g. Benson et al., 2012). Most notably, the shift in habitat preference is coupled with

62 the emergence of the characteristic plesiosaurian bauplan which is foreshadowed in the

63 Pistosauridae (Sues, 1987). It is characterized by a complete transformation of the

64 extremities to stiff flippers, a shortening of the trunk and tail, and an elongation of the

65 neck (the latter is secondarily shortened, however, in several derived plesiosaurian groups). These characters correspond to a unique mode of paraxial locomotion ("fourwinged under-water flight"), which enabled plesiosaurs to effectively propel themselves through the water combined with great maneuverability. Shallow-water eosauropterygians, on the other hand, swam by axial undulation supported by the limbs to varying degrees (e.g., Nothosauroidea, basal Pistosauroidea) (Zhang et al., 2014;

71 Klein, 2015).

72 The physiological consequences of offshore environment colonization in sauropterygians remain largely unexplored. Basal eosauropterygians, such as pachypleurosaurids, already reproduced and presumably spent their whole life in coastal waters (Sander, 1988; Cheng et al., 2004). Still, the available data suggest important physiological changes in response to the adaptation to open marine habitats in more derived groups. Qualitative and quantitative osteohistological investigations of eosauropterygians inferred elevated metabolic rates for pistosauroids, thereby suggesting endothermy in this group (Klein, 2010: Krahl et al., 2013; Wintrich et al., 2017; Fleischle et al., 2018). These results conform to those from studies on isotope composition of plesiosaurian tooth phosphate (Bernard et al., 2010). Enhanced metabolic rates apparently facilitated dispersal into pelagic habitats around the globe (Krahl et al., 2013; Wintrich et al., 2017) and evolved convergently in other marine reptile groups as well (Bernard et al., 2010). Apart from that, the morphology of the endosseous labyrinth in diverse sauropterygians traces the shift in locomotory style subsequent to the colonization of marine habitats (Neenan et al., 2017). Pistosauroids gradually evolved a distinct compact inner ear morphology similar to extant marine turtles, while the inner ear of basal sauropterygians more closely resembles the condition found in extant crocodiles and marine iguanas (Neenan et al., 2017). This indicates a more sophisticated diving profile in the former group. In accordance with

91 this, avascular necrosis has repeatedly been reported for pistosauroids throughout their 
92 evolutionary history (Rothschild \& Storrs, 2003; Surmik et al., 2017). In extant tetrapods,

93 this type of bone tissue lesion is indicative of decompression syndrome (Carlsen, 2017).

94 In pachypleurosaurs and nothosauroids, these lesions are almost completely absent

95 (Rothschild \& Storrs, 2003), again suggesting contrasting lifestyles and diving behavior

96 in these basal groups compared to pistosauroids.

97 So far, physiological adaptations to pelagic lifestyles on the cellular level received no 98 attention in sauropterygians or other fossil marine reptiles. Obviously, data on cellular characteristics in most fossil vertebrates have to be inferred from bone tissue. In petrographic thin-sections of fossil bone, its microstructure, including vascularization, can be studied in detail. The caliber of the smallest vascular canals found in bone tissue tightly correlates with the size of the erythrocytes, the oxygen-transporting red blood cells (RBC) of the respective species, allowing the reconstruction of RBC size in extinct taxa via regression models (Huttenlocker \& Farmer, 2017). Due to their pivotal role in systemic oxygen transport, RBC size can potentially provide further information on pelagic adaptations in sauropterygians.

In the context of marine mammal research, it has been hypothesized that secondarily aquatic species tend to evolve enlarged RBCs (Wickham et al., 1989). Large RBCs can store increased amounts of hemoglobin to allow for persistent tissue oxygen-supply during prolonged dives, providing adaptive advantages for pelagic species (Wickham et

111 al., 1989; Promislow, 1991). However, comparisons between RBC parameters in

112 marine amniotes and their terrestrial relatives have only superficially been undertaken,

113 and potential patterns of convergence remain unappreciated (compare Hawkey, 1975).

114 In general, mammals have the smallest RBCs among amniotes related to the

115 evolutionary loss of the nucleus and bird RBC size is lower than in modern reptiles,

116 presumably because of the general inverse relationship between metabolic rate and

117 RBC size observed in vertebrates (e.g., Gregory, 2002).

118 In this study, we analyze osteohistological features of diverse eosauropterygian taxa to

119 trace RBC size evolution across the nothosaurian-pistosaurian transition in order to

120 identify correlates of pelagic adaptation. We hypothesized that pistosauroids have

121 relatively larger vascular canals indicative of enlarged RBCs compared to

122 pachypleurosaurs and nothosauroids. This condition would be in accordance with 
123 advanced pelagic adaptations in the former group. To track RBC size evolution, we 124 apply phylogenetic eigenvector maps (PEM) (Guénard et al. 2013). This technique is 125 increasingly used in recent histomorphometric studies (Legendre et al., 2016; Olivier et

126 al., 2017; Fleischle et al., 2018) and allows estimating unknown trait values from a 127 predictor variable while taking into account phylogenetic relationships. Inferring 128 hematological parameters to deduce ecophysiological adaptations is a novel approach 129 which has not been considered in marine reptile paleobiology before. To complement 130 our inferred data on sauropterygians and to test for influences of body size and ecology 131 on RBC size parameters in extant groups, we additionally compiled RBC size

132 measurements for modern reptiles, birds and mammals with a focus on marine groups.

133 Different RBC size proxies pertain in the literature, at times hindering effective

134 comparisons. Whereas cell volume would appear to be the most useful proxy and

135 indeed has been widely used (see below), other size proxies are two-dimensional

136 ("area") or one-dimensional ("width","length"). We employed all of these size proxies in

137 our study, the choice depending on availability of comparative data sets. Vertebrate

138 RBC shape is typically that of an oblate to scalenoid spheroid (Gulliver, 1862). The most

139 common proxies used to describe RBC size are "area", "width" and "length". "Area"

140 describes the lateral surface area of the disc-shaped erythrocyte as seen under a light

141 microscope. "Length" corresponds to the longest axis (diameter) that can be drawn on

142 the RBC, while "width" denotes the shortest one (Hartman \& Lessler, 1964). RBC

143 volume is either measured directly or can be calculated based on the other proxies, as

144 done in the current study for fossil species.

146 Materials \& Methods

148 Fossil sample base

149 We studied petrographic histological thin-sections of fossil bones from 13

150 eosauropterygian taxa, most of which were already included in earlier studies (table 1).

151 Among the basal Eosauropterygia, we examined several species of pachypleurosaurids

152 (Anarosaurus heterodontus, Neusticosaurus edwardsii, Neusticosaurus peyeri,and

153 Neusticosaurus pusillus) and a nothosaurid (Nothosaurus sp.). Among Pistosauroidea, 
154 we included the basal taxa Cymatosaurus sp. and Pistosaurus longaevus

155 ("Pistosauridae") as well as diverse plesiosaurs (Plesiosaurus dolichodeirus,

156 Rhaeticosaurus mertensi, Pliosaurus sp., Cryptoclidus eurymerus, Polycotylus

157 latipinnus, and an indeterminate Japanese elasmosaurid). We collected

158 histomorphometric data in petrographic thin sections of 50-80 $\mu \mathrm{m}$ thickness from

159 stylopodial (humerus/femur) mid-diaphyses by analyzing microscopic images taken with

160 a Leica DFC420 color camera mounted on a polarizing microscope (Leica DM2500LP)

161 using the software EASYLAB 7 (Fig. 2). We also took overview images of thin-sections

162 with an Epson V750 scanner. Contrasting with stylopodials from other marine amniotes,

163 such as cetaceans and ichthyosaurs, the respective bones in plesiosaurs do not show

164 an increase in the amount of primary cancellous bone at the expense of a compact

165 cortex.

166

167

Measurement and inference of eosauropterygian RBC size

168

In their study, Huttenlocker and Farmer (2017) found a correlation of minimum and

169 mean vascular canal with RBC size (area and width) in extant amniotes. Applying the R package MPSEM (Guénard et al., 2013), we converted the phylogeny of the extant species (adopted from Huttenlocker \& Farmer, 2017) into PEMs to build the predictive models. Both potential predictor variables, i.e., minimum and mean canal caliber, and

173 the estimated variables (RBC area and width) (all data taken from Huttenlocker \&

174 Farmer 2017) were log-transformed to adjust for the large range of values in the data set. We selected minimum canal caliber as the best predictor variable based on the Akaike information criterion, corrected for small sample size (AICc) (Burnham et al., 2011) and cross-validated using leave-one-out cross-validation, suitable for a small

178 training data set.

179 The fossil eosauropterygians were then added to the tree of predicting species. Since a

180 sister group relationship of Sauropterygia and Lepidosauromorpha is commonly

181 accepted (Rieppel, 2000; Chen et al., 2014; but see Kelley \& Pyenson 2015), it was

182 adopted in our study. For internal eosauropterygian relationships, we used the

183 phylogeny of Rieppel (2000), depicting a monophyletic Pachypleurosauridae as the

184 sister group to Eusauropterygia which includes Nothosaurus and Pistosauroidea (Fig. 
185 1). For pistosauroid ingroup relationships, were entered a topology based on Ketchum 186 and Benson (2010) and Wintrich et al. (2017). Using the model, we estimated RBC area 187 and width for each fossil specimen (table 1), including the $95 \%$ confidence intervals. For 188 the statistical comparison of basal sauropterygians and pistosauroids, we used a Welch 189 two sample t-test.

190 For the comparison of the fossils with the RBC volume data sets for extant taxa

191 compiled by us, we calculated RBC volume (V), from estimated RBC width and area (A) 192 of the fossils. We approximated sauropterygian RBC shapes as a scalenoid spheroid,

193 i.e., a spheroid that has three different axes, because this is the shape of modern

194 RBCs. The major axis is length (a), the intermediate axis is width (b), and the minor axis 195 is (c).

196 In a first step, we calculated a as

197

$$
a=(4 A) /(b \pi)
$$

For calculating $\mathrm{V}$, we made one additional assumption, i.e. that $\mathrm{c}$ is half of $\mathrm{b}$, i.e., that the minor axis is half the length of the intermediate axis. Using length $a$, width $b$, and minor diameter $\mathrm{c}$, we calculated volume $\mathrm{V}$ as follows:

203

$V=(1 / 6) \pi a b c$

205

\section{RBC and body mass parameters in extant taxa}

To analyze potential influences of body mass and ecology on RBC size in different clades and between taxonomic ranks, we compiled a dataset of RBC size parameters (area, width, length, depending on the available data) and body mass for 188 species of

210 extant reptiles (lepidosaurs, turtles and crocodiles) from the literature (see tables S6,

211 S7). Given their phylogenetic affiliation, such patterns in extant reptiles, especially in

212 lepidosaurs, can be hypothesized to bear relevant implications for sauropterygians. In

213 addition to this, we collected published RBC volume data on selected marine mammals

$214(n=28)$ and birds $(n=6)$ as well as non-marine representatives of these groups

$215\left(\mathrm{n}_{\text {Mammalia }}=82 ; \mathrm{n}_{\text {Aves }}=36\right)$ (see tables S8, S9) in order to further test if adaptation to 
216 pelagic life correlates with specific trends in amniote RBC size evolution. Variance in the

217 compiled data sets was assessed by means of the Kruskal-Wallis test, and differences

218 between marine and non-marine groups were assessed by applying the Welch two-

219 sample t-test. In case several measurements were found for the same species, data

220 were averaged.

221

222

\section{Results}

223

224

225

\section{Red blood cell size in Eosauropterygia}

Estimated RBC size as expressed by RBC area for the basal sauropterygian

226

pachypleurosaurids and Nothosaurus is consistently small (species means ranging from

227 65.75 - $82.84 \mu \mathrm{m}^{2}$; group mean: $75.81 \mu \mathrm{m}^{2}$; table 2, Fig. 3) compared to pistosauroids. For the latter, inferred RBC area is notably larger (species means ranging from 96.45 $220.93 \mu \mathrm{m}^{2}$; group mean: $144.98 \mu \mathrm{m}^{2}$; table 2, Fig. 3). The Welch Two Sample t-test, comparing estimated RBC areas of the basal sauropterygians and pistosauroids, respectively, yields significant differences between the two groups $(t=-5.1768, p<$ $0.001, \mathrm{df}=8$ ). Concerning group average RBC volumes, an increase of $270 \%$ from pachypleurosaurids and Nothosaurus (group mean: $197.7 \mu \mathrm{m}^{3}$ ) to the more derived pistosauroids (group mean: $533.8 \mu \mathrm{m}^{3}$ ) was obtained. For measured canal calibers see table S1, for PEM models and model coefficients for RBC parameter inference, see tables S2, S3; for estimated RBC size proxies and confidence intervals, see tables S4, S5.

238

\section{Body mass and RBC size in extant reptiles}

We found evidence for a weak influence of body mass on RBC size in reptiles using the size proxies area and length among extant reptile species (Fig. 4). When data of

242 lepidosaurs, turtles and crocodylians are combined, a weak but statistically highly significant correlation emerges (area: adjusted $R^{2}=0.104, p$-value $=0.00017, d f=120$; length: adjusted R2=0.3373, p-value $<0.00001$, df=178; Fig. 4). At lower taxonomic ranks however, this correlation was not consistently recovered (Fig. S1). For example, turtle RBC length (Testudines, $n=31$, adjusted $R^{2}=0.488, p=0.02$ ) and RBC area in 
247 true lizards (Lacertidae, $n=21$, adjusted $R^{2}=0.218, p=0.02$ ) correlated significantly

248 with body mass, whereas RBC area in colubrid snakes instead showed an inverse

249 statistical trend (Colubridae, $n=42$, adjusted $R^{2}=-0.018, p=0.48$ ) (Fig. S1).

250

251 RBC size and aquatic adaptation in extant taxa

252 An increase in RBC size in marine taxa compared to related terrestrial groups was

253 consistently found among secondarily aquatic amniotes (Fig. 5). Within this comparison,

254 volume is the RBC size proxy for mammals and birds, and area is the size proxy for

255 reptiles. All aquatic mammal clades exhibit RBC volumes significantly above the

256 terrestrial mammal mean, which was recovered as $64 \mu \mathrm{m}^{3}$ based on data from a

257 selection of terrestrial mammal species ( $n=82$; SD: 25.19 ; table S8). In seals

258 (Pinnipedia; $n=12$ ), the mean RBC volume is $127.8 \mu \mathrm{m}^{3}$ (SD: 26.00 ), which equals

$259195.6 \%$ of the average volume in closely related non-marine carnivoran species of the

260 superfamily Canoidea, in which pinnipeds are nested $\left(n=15\right.$; mean: $65.35 \mu \mathrm{m}^{3}$; SD:

261 9.33), and $199.7 \%$ of the terrestrial mammal mean value, respectively (Fig. 5). The two

262 sampled pinniped families differ notably in RBC size, with members of the Otariidae $(n=$

2634 , range: $\left.97-108 \mu m^{3}\right)$ displaying smaller RBCs than the ones of the Phocidae $(n=8$;

264 range: $105-176 \mu \mathrm{m}^{3}$ ). Besides pinnipeds, the RBC volume of the sea otter (Enhydra

265 lutris) $\left(113 \mu \mathrm{m}^{3}\right)$ is also strongly increased (172.9\%) compared to non-marine canoids.

266 In cetaceans ( $n=14$; mean: $121.28 \mu m^{3}$; SD: 24.58 ), the mean RBC volume even was

$267297 \%$ of that of ruminant artiodactyls (Ruminantia; $n=16$; mean: $40.83 \mu \mathrm{m}^{3}$; SD:

268 15.19), which are among the whales' closest living relatives, and $189.5 \%$ that of the

269 terrestrial mammal mean (Fig. 5). RBC volume ranges of terrestrial and aquatic

270 carnivorans as well as whales and terrestrial ungulates do not overlap. While clearly

271 deviating from the ones of their close extant relatives as well as from the mammalian

272 mean ( $p<0.001$ for all comparisons), RBC volumes in pinnipeds and cetaceans do not

273 significantly differ from each other $(p=0.052)$. Data on sirenians could only be obtained

274 for one species, Trichechus manatus, the mean RBC volume of which is also notably

275 large at $132.6 \mu^{3}$ (Medway et al., 1982) (Fig. 5).

276 Like marine mammals, penguins, as diving marine birds, exhibit markedly enlarged

277 RBCs compared to other birds (Fig. 5). However, compared to the mammalian groups, 
278 the relative increase in RBC volume is less pronounced. The mean RBC volume of 279 penguins (Sphenisciformes; $n=6$; mean: $239.7 \mu \mathrm{m}^{3}$; SD: 26.24 ) is $140 \%$ of that of 280 closely related sea birds (Aequornithes sensu Burleigh et al. (2015); $\mathrm{n}=6$; mean:

$281171.84 \mu \mathrm{m}^{3}$; SD: 28.66 ) and $169 \%$ that of the avian average (non-Sphenisciformes; $n=$ 282 36; mean: $141.97 \mu \mathrm{m}^{3}$; SD: 27.82). The volume of penguin RBCs differs significantly 283 from the one of both other sea birds $(p=0.002)$ as well as from the avian mean $(p<$ 284 0.001). In our sample, the only other bird within the penguin RBC volume range is the 285 blue-eyed shag (Phalacrocorax atriceps), a deep-diving marine cormorant.

286 Data availability for extant marine reptile groups was far more restricted, consisting of 287 data sets for either RBC area or RBC length and having incomplete taxonomic 288 coverage. However, less extreme disparities between marine and non-marine reptile 289 groups were observed compared to the endothermic amniotes. Laticauda colubrina is 290 the only marine squamate within our dataset. With an RBC area of ca. $170 \mu \mathrm{m}^{2}$, it 291 exhibits the largest RBCs of the family Elapidae. Laticauda RBCs show $126 \%$ of the 292 mean area reported for elapids $\left(n=7\right.$; range: $114.5-162 \mu \mathrm{m}^{2}$; mean: $\left.134,5 \mu \mathrm{m}^{2}\right)$ but 293 are approached in area by those of terrestrial species such as Pseudechis australis $294\left(162 \mu \mathrm{m}^{2}\right)$ (see supplements). A similar pattern of limited size disparity depending on 295 ecology was found for turtles. The mean lengths of marine turtle RBCs are significantly 296 larger compared to those of freshwater cryptodire turtles, (marine species: $22.74 \mu \mathrm{m}, \mathrm{n}$ 297 = 7; non-marine species: $20.10 \mu \mathrm{m} ; \mathrm{n}=20, \mathrm{p}<0.001$ ). Nevertheless, there is a size 298 range overlap between the groups.

299

300 Discussion

301

302

303 Our analysis is strongly dependent on the availability of data for extant species. Since plesiosaurs display an extremely derived morphology and because the phylogenetic position of Sauropterygia has not been unequivocally determined, phylogenetic models for estimating trait values for this group may be biased. Our PEM model on RBC size parameters was based on RBC and vascular canal dimension data published by 
309 amniote clades, overall diversity and species number in the sample is low. Our results

310 are thus open to testing by expanding the given dataset for extant taxa. In addition, we

311 suspect a phylogenetic influence on the generally larger size of RBCs in reptiles, to

312 which plesiosaurs belong, compared to mammals and birds.

313

314 RBC size evolution in eosauropterygians: Effects of body mass, genome size and 315 metabolic rate

316 RBCs show a notable difference in size (area as well as volume) between basal

317 eosauropterygians and the pistosauroids. Species of pistosaurid grade have values

318 intermediate between the basal groups and plesiosaurs. When compared to modern

319 taxa, the inferred RBC parameters of eosauropterygians fall well within the range of

320 extant non-avian reptiles which generally have the largest RBCs of all amniotes. While

321 basal sauropterygians show inferred RBC sizes (area, length and width) similar to the

322 lowest values obtained for squamates, the inferred values for plesiosaurs indicate large

323 RBCs, comparable in size to those of turtles or large squamate RBCs (Table 1 and S6).

324 Our estimates therefore lie within a biologically reasonable range.

325 RBC size might be affected by body mass. Eosauropterygians cover a wide mass

326 range, from the diminutive pachypleurosaurids to some plesiosaurs exceeding $10 \mathrm{~m}$ in

327 length. Studies in extant sauropsids demonstrate that RBC size and also cell sizes in

328 various other tissues vary between individuals as well as between species of disparate

329 mass (Venzlaff, 1911; Hartman \& Lessler, 1963; Frair, 1977; Kozlowski et al., 2010;

330 Frýdlová et al., 2013). For RBC area, a close correlation with body mass has been

331 demonstrated for example in eublepharid geckos (Starostová et al., 2005). Our own

332 dataset on reptile RBCs also suggests that there is a weak but highly significant

333 correlation across ectothermic amniotes in general and also in various lower ranking

334 groups. Nevertheless, against the background of weak scaling effects, it appears that

335 the observed patterns are too divergent to be exclusively related to body mass increase.

336 Accordingly, we do not consider evolutionary body mass increase to be the major

337 explanation for the observed difference in cell size parameters in basal versus derived

338 eosauropterygians. 
339 Several studies concluded that vertebrate genome size closely correlates with cell size

340 (Olmo \& Odierna, 1982; Gregory, 2000; Gregory, 2001), suggesting that an increase in

341 genome size might have resulted in the enlargement of RBCs in the sauropterygian

342 lineage. However, results of these studies have proven to be problematic, especially as

343 cause and effect of the observed correlation remain obscure. Investigations on cell and

344 genome size usually concentrate on high taxonomic ranks and often include only small

345 samples from specific subgroups. General correlations between cell size and genome

346 size might simply reflect physiological constraints acting in conjunction with non-

347 adaptive fluctuations in genome size, without universal implications for specific taxa

348 (Pagel \& Johnstone, 1992; Starostová et al., 2008). For example, a detailed study on

349 RBCs and genome sizes in eublepharid geckos did not reveal a significant correlation

350 between the two parameters (Starostováet al., 2008). Similarly, inconsistent patterns

351 are also known from other tetrapod groups, such as artiodactyls (Gregory, 2000).

352 Comparative data on cell and genome size at lower taxonomic ranks could potentially

353 provide compelling evidence for a close correlation between the two or might elucidate

354 the proposed link between genome size and cell size. The high mass-specific basal

355 metabolic rate in pistosauroids (Bernard et al. 2010, Krahl et al., 2013; Fleischle et al.,

356 2018), which is expected to correlate with a decrease in genome size (Gregory, 2002;

357 Kozlowski et al., 2003; Vinogradov \& Anatskaya, 2006) sheds further doubt on the

358 hypothesis that major genome expansions occurred during eosauropterygian evolution.

359 As a consequence, we do not consider genome expansion a convincing explanation for

360 evolutionary RBC size increase in Sauropterygia.

361

362 Adaptive significance of secondarily enlarged RBCs in plesiosaurs and other 363 marine amniotes

364 An increase in RBC size appears to be a ubiquitous, albeit not generally acknowledged,

365 adaptation among secondarily aquatic amniotes. By comparing RBC parameters of

366 marine groups with those of their respective non-marine relatives, we consistently found

367 enlarged RBCs in the former, most prominently in mammals. In both birds and

368 mammals, the largest RBCs incorporated in our dataset derive from pelagic specialists.

369 The relative size increase of RBCs was largest in cetaceans which displayed on 
370 average $297 \%$ of the mean RBC volume found in the closely related ruminants.

371 However, it should be noted that artiodactyls show an unusually broad spectrum of RBC

372 sizes, including the smallest ones known in mammals (Gregory, 2000). This likely

373 biased the recovered relative RBC size increase in cetacean evolution. Interestingly, our

374 finding of consistently enlarged RBCs in marine amniotes calls a recent hypothesis on

375 the hematology of ichthyosaurs into question. Plet et al. (2017) recovered microscopic

376 disc-shaped structures from a Jurassic ichthyosaur vertebra encapsulated in a

377 carbonate concretion and interpreted them as miniaturized RBCs. Like plesiosaurs,

378 ichthyosaurs were large pelagic endotherms (e.g. Bernard et al., 2010), so that an

379 increase rather than a reduction of RBC size in this taxon would be expected, based on

380 our dataset.

381 Increasing RBC size might at first appear to be maladaptive in sustainably active

382 aquatic endothermic animals. Enlarged RBCs are less effective than smaller cells in

383 providing surrounding tissues with oxygen because of their reduced relative surface

384 area, which restricts the diffusion of gas molecules (Lay \& Baldwin, 1999; Nicol et al.,

385 1988). With increasing RBC volume, the rate of oxygen uptake and release,

386 respectively, within a specific time period is steadily reduced (Holland \& Forster, 1966).

387 However, since greater quantities of hemoglobin can be stored in each individual cell,

388 larger RBCs can maintain tissue oxygen supply for a longer time interval than smaller

389 ones at a constant hematocrit level (Wickham et al., 1989; Promislow, 1991). This is

390 especially relevant for prolonged aerobic dives, facilitating foraging in pelagic habitats.

391 Possibly, this advantage outweighs potential risks related to the formation of RBC

392 aggregations, which are apparently tolerated by marine mammals to a degree

393 hypercritical to terrestrial species (Castellini et al., 2006). The prevalence of enlarged

394 RBCs in deep diving flying species, such as the blue-eyed shag, which would otherwise

395 benefit from smaller cells, further supports an adaptive value of this trait. Apart from this,

396 enlarged RBCs have been controversially hypothesized to be advantageous for pelagic

397 specialists by altering blood rheology (Block \& Murrish, 1974; Castellini et al., 2010). In

398 amniotes, RBC size is inversely correlated with RBC counts (Hartman \& Lessler, 1963;

399 Hawkey et al., 1991). Marine tetrapods exhibiting large RBCs therefore have low RBC

400 counts compared to terrestrial taxa while exhibiting higher hematocrit values (Nicol et 
401 al., 1988; Wickham et al., 1989; Hedrick \& Duffield, 1991). This condition was reported

402 to reduce blood viscosity at relevant shear rates and proposed to aid in sustaining

403 tissue perfusion and effective circulation during diving cycles (Wickham et al., 1989;

404 Clarke \& Nicol, 1993). However, other reports offer contrasting results (Block \& Murrish,

405 1974; Hedrick \& Duffield, 1991). Thus, currently available data fail to produce a

406 conclusive picture of the matter (Castellini et al., 2010).

407 Interestingly, relative RBC size increase in extant marine reptiles appears to be far less

408 pronounced than in endotherms. However, this conclusion is tentative and calls for

409 further investigation, as informative data are extremely scarce. The limited data suggest

410 that, as in endotherms, marine specialists among reptiles tend to evolve larger RBCs,

411 but the size increase is far more limited. In turtles, a group in which individual as well as

412 species-specific body mass has a notable influence on RBC size (Frair, 1977), the

413 consistently larger body mass of marine species might additionally contribute to the

414 observed cell enlargement compared to limnic groups. The potential difference in

415 relative RBC size increase in endotherms and ectotherms could be linked to the

416 divergent oxygen demands in the respective groups. However, this preliminary

417 hypothesis requires support from further hematological studies on marine reptiles.

418 Extant marine reptiles appear to be of limited use in the comparison with plesiosaurs, in

419 particular, because of the differences in basal metabolic rate.

420 The largest RBCs in each group studied are predominately found in species that

421 routinely dive to great depths such as sea elephants and bottom-feeding monodontid

422 whales (MacNeill, 1975; Hedrick \& Duffield, 1991; but compare Ridgway et al., 1970).

423 Following this pattern, phocid seals, which tend to dive deeper and for longer durations

424 than their otariid relatives (Debey et al., 2013), have consistently larger RBCs. However,

425 shallow-water inhabitants such as the Chinese river dolphin (Lipotes vexillifer) can

426 exhibit remarkably large RBCs as well, while comparatively small cells can occur in

427 deep diving species. For example, the king penguin (Aptenodytes patagonicus), which

428 is among the most extreme avian divers, reaching depths of more than $300 \mathrm{~m}$

429 (Kooyman et al., 1992), displays the smallest RBCs within our penguin sample.

430 Accordingly, there appears to be no tight correlation between diving depth and RBC

431 size within a specific group. Further research needs to elucidate factors influencing RBC 
432 size variations within taxa of shared ecology. However, it can be robustly stated that

433 relative taxon-wide RBC enlargement is associated with aquatic adaptation, at least in 434 endotherms.

435 Given the collective evidence from extant species, we suggest that the demands posed 436 by foraging in offshore environments and elevated metabolic rates drove the evolution

437 of significantly enlarged RBCs in the Pistosauroidea. Following that, we hypothesize low 438 RBC counts and high hematocrit values in plesiosaurs, mirroring the situation found in 439 penguins, whales and seals.

440 The inferred RBC volume difference (270 \%) between basal eosauropterygians and 441 pistosauroids is comparable to the difference between fully aquatic and terrestrial 442 species seen in modern mammals. It is therefore more extreme than expected, given 443 that pachypleurosaurids and especially Nothosaurus were already well adapted 444 inhabitants of coastal waters. However, adaptive shifts in RBC size of, for example in 445 Nothosaurus, were probably relatively small when compared with its terrestrial 446 forerunners, as the size increase in modern reptilian analogues suggest. Subsequently, 447 RBC size in more derived eosauropterygians of the pistosaurid clade notably increases, 448 as did basal metabolic rate (Fleischle et al., 2018). As already described above, RBC 449 size usually scales negatively with metabolic rate. In the specific case of endothermic 450 aquatic amniotes, however, elevated respiratory demands apparently override the 451 metabolic pressures limiting RBC size and favor enlarged cells. The optimized 452 hematology of pistosauroids was gradually acquired in species of the pistosaurid clade. 453 Therefore, its evolution coincided not only with the emergence of elevated metabolic 454 rates but also changes in sensory ecology, locomotion, and diving profiles compared to 455 pachypleurosaurids and nothosaurids (Sues, 1987; Neenan et al., 2017; Surmik et al., 456 2017). All of these traits prepared the emergence of the Plesiosauria in the Late 457 Triassic. The divergent hematology of the groups concerned should therefore be viewed 458 as another expression of ecological separation between them.

459 For species-specific RBC size interpretations, we suggest a cautious approach with 460 respect to ecology. As noted above, RBC size variation does not correlate tightly with 461 suggestive behavioral differences such as diving depth and duration in extant aquatic 462 amniotes. This complicates detailed inferences for fossil taxa. For example, we 
463 estimated a remarkably large RBC size for the plesiosaur Pliosaurus sp. (table 2, Fig.

4643 3). While this could be interpreted as an indication of deep and prolonged diving in this

465 genus, the inconsistent patterns observed in extant marine amniotes ask for more

466 cautious considerations. A broader sampling of extant as well as fossil taxa is needed to

467 convincingly evaluate ecological signals at the level of the genus or species.

468

\section{Conclusions}

470 Our results support previous studies proposing an ecophysiological separation between

471 basal eosauropterygians of coastal environments and the increasingly pelagic

472 pistosauroids. Living in offshore habitats necessitates proficient diving abilities, which in

473 consequence must have required physiological adaptations to prolonged submersion in

474 pistosauroids. Large RBCs and the thereby enhanced constant oxygen supply to

475 somatic tissues would have facilitated deep diving, which also is the case in numerous

476 modern clades of pelagic amniotes. Estimates of RBC size in pistosauroids suggests

477 remarkably large RBCs in this group, thereby supporting the view of especially

478 plesiosaurs as predominately pelagic animals. The RBC size increase evolved

479 simultaneously with the plesiosaurian bauplan in basal pistosauroids and coincided with

480 the emergence of a unique bone microstructure (Krahl et al., 2013) and compact inner

481 ear morphologies (Neenan et al. 2013). All of these findings support the assumption that

482 basal pistosauroids, such as Cymatosaurus and Pistosaurus, gradually adapted to an

483 offshore lifestyle during the Middle Triassic. However, RBC size apparently does not

484 represent a reliable proxy to infer specific ecological niches and diving depths, as

485 comparisons with extant species demonstrate.

486 We suggest that studies on the hematology of other fossil groups have the potential to

487 unveil and date the emergence of specific ecological adaptations and to test hypotheses

488 put forward herein. We also encourage further studies on extant marine amniotes to

489 allow for refined inferences for fossil taxa. So far, RBC evolution appears to represent a

490 remarkable example of adaptive convergence between Mesozoic marine reptiles,

491 oceanic mammals and pelagic diving birds.

492

\section{Acknowledgements}


494 We thank Olaf Dülfer and Pia Schucht for producing the histological thin sections used in this

495 study and all curators at the respective institutions for the permission for histological sampling.

496 We are grateful to Shoji Hayashi and Yasuhisa Nakajima for providing the elasmosaurid sample

497 and to Lucas Legendre and Jorge Cubo for assistance with statistical modeling. We thank

498 Sabine Begall and Jun Liu for critical feedback and comments during preparation of the initial

499 draft and Bruce Rothschild as well as one anonymous reviewer for constructive criticism that

500 improved the original manuscript.

501

\section{References}

503 Benson, R.B. \& Druckenmiller, P. S. (2014). Faunal turnover of marine tetrapods during the

504 Jurassic-Cretaceous transition. Biological Reviews 89: 1-23.

505

506

Benson, R. B., Evans M., \& Druckenmiller, P. S. (2012). High diversity, low disparity and small

507

body size in plesiosaurs (Reptilia, Sauropterygia) from the Triassic-Jurassic boundary. PLoS

508

One 7: e31838.

509

510

Bernard, A., Lécuyer, C., Vincent, P., Amiot, R., Bardet, N., Buffetaut, E., ... \& Prieur, A. (2010).

Regulation of body temperature by some Mesozoic marine reptiles. Science 328: 1379-1382.

512

513

Block, G. A., \& Murrish, D. E. (1974). Viscous properties of bird blood at low

514 temperatures. Antarctic Journal of the United States, 9: 98-99.

515

516

Burleigh, J. G., Kimball, R. T., \& Braun, E. L. (2015). Building the avian tree of life using a large-

517 scale, sparse supermatrix. Molecular Phylogenetics and Evolution 84:53-63.

518

519

Burnham, K. P., Anderson, D. R., \& Huyvaert, K. P.(2011). AIC model selection and multimodel inference in behavioral ecology: some background, observations, and comparisons. Behavioral Ecology and Sociobiology 65: 23-35.

522

523 Carlsen, A. W. (2017). Frequency of decompression illness among recent and extinct mammals 524 and "reptiles": a review. The Science of Nature 104:56. 
526 Castellini, M., Baskurt, O., Castellini, J. M., \& Meiselman, H. J. (2010). Blood rheology in marine 527 mammals. Frontiers in Physiology 1:146.

528

529 Castellini, M., Elsner, R., Baskurt, O. K., Wenby, R. B., \& Meiselman, H. J. (2006). Blood

530 rheology of Weddell seals and bowhead whales. Biorheology 43:57-69.

531

532 Chen, X. H., Motani, R., Cheng, L., Jiang, D. Y. \& Rieppel, O (2014). The enigmatic marine

533 reptile Nanchangosaurus from the Lower Triassic of Hubai, China and the phylogenetic affinities

534 of Hupehsuchia. PLoS One 9: e102361.

535

536 Cheng, Y. N., Wu, X. C., \& Ji, Q. (2004). Triassic marine reptiles gave birth to live young. Nature 537 432: 383-386.

538

539 Clarke, J., \& Nicol, S. (1993). Blood viscosity of the little penguin, Eudyptula minor, and the

540 Adelie penguin, Pygoscelis adeliae: effects of temperature and shear rate. Physiological

541 Zoology 66:720-731.

542

543 Cubo, J., Le Roy, N., Martinez-Maza, C., \& Montes, L.P. (2012). Paleohistological estimation of

544 bone growth rate in extinct archosaurs. Paleobiology 38:335-349.

545

546 Debey, L. B., \& Pyenson, N. D. (2013). Osteological correlates and phylogenetic analysis of 547 deep diving in living and extinct pinnipeds: What good are big eyes?. Marine Mammal Science 548 29:48-83.

549

550 Farke, A. A. (2007). Reexamination of paleopathology in plesiosaurs and implications for 551 behavioral interpretations. Journal of Vertebrate Paleontology, 27:724-726.

552

553 Fleischle, C. V., Wintrich, T. \& Sander, P. M. (2018) Quantitative histological models suggest

554 endothermy in plesiosaurs. PeerJ, 6: e4955.

555

556 Frair, W. (1977). Sea turtle red blood cell parameters correlated with carapace

557 lengths. Comparative Biochemistry and Physiology Part A: Physiology 56:467-472. 
559 Frýdlová, P., Hnizdo, J., Chylikova, L., Šimková, O., Cikanova, V., Velenský, P., \& Frynta, D.

560 (2013). Morphological characteristics of blood cells in monitor lizards: is erythrocyte size linked

561 to actual body size?. Integrative Zoology 8:39-45.

562

563 Gregory, T. R. (2000). Nucleotypic effects without nuclei: genome size and erythrocyte size in

564 mammals. Genome 43:895-901.

565

566

Gregory, T. R. (2001). The bigger the C-value, the larger the cell: genome size and red blood cell size in vertebrates. Blood Cells, Molecules, and Diseases 27:830-843.

Gregory, T. R. (2002). A bird's-eye view of the C-value enigma: genome size, cell size, and metabolic rate in the class Aves. Evolution 56:121-130.

571

572

Guénard, G., Legendre, P., \& Peres-Neto, P. (2013). Phylogenetic eigenvector maps: a

framework to model and predict species traits. Methods in Ecology and Evolution 4:1120-1131.

574

575

Gulliver, G. (1862). On the red corpuscles of the blood of vertebrata, and on the zoological

import of the nucleus, with plans of their structure, form, and size (on a uniform scale), in many

of the different orders. Proceedings of the Zoological Society of London 30:91-103.

578

Hartman, F. A., \& Lessler, M. A. (1963). Erythrocyte measurements in birds. The Auk, 80: 467473.

581

582

Hawkey, C. M. (1975). Comparative mammalian haematology: cellular components and blood coagulation of captive wild animals. William Heinemann Medical Books, London.

584

Hawkey, C. M., Bennett, P. M., Gascoyne, S. C., Hart, M. G., \& Kirkwood, J. K. (1991).

Haematology 77: 392-397.

Hedrick, M. S., \& Duffield, D. A. (1991). Haematological and rheological characteristics of blood in seven marine mammal species: physiological implications for diving behaviour. Journal of

591 Zoology 225: 273-283. 
593 Holland, R. A. B., \& Forster, R. E. (1966). The effect of size of red cells on the kinetics of their

594 oxygen uptake. The Journal of General Physiology 49: 727-742.

595

596 Huttenlocker, A. K. \& Farmer, C. G. (2017). Bone microvasculature tracks red blood cell size

597 diminution in Triassic mammal and dinosaur forerunners. Current Biology 27:48-54.

598

599

Jiang, D. Y., Motani, R., Tintori, A., Rieppel, O., Chen, G. B., Huang, J. D., .. \& Ji, C. (2014).

600 The Early Triassic eosauropterygian Majiashanosaurus discocoracoidis, gen. et sp. nov.

601 (Reptilia, Sauropterygia), from Chaohu, Anhui Province, People's Republic of China. Journal of

602 Vertebrate Paleontology, 34: 1044-1052.

603

604 Kelley, N. P. \& N. D. Pyenson. 2015. Evolutionary innovation and ecology in marine tetrapods

605 from the Triassic to the Anthropocene. Science 348: aaa3716.

606

607 Ketchum, H. F. \& R. B. Benson (2010). Global interrelationships of Plesiosauria (Reptilia,

608 Sauropterygia) and the pivotal role of taxon sampling in determining the outcome of

609 phylogenetic analyses. Biological Reviews 85: 361-392.

610

611 Klein, N. (2010). Long bone histology of Sauropterygia from the Lower Muschelkalk of the

612 Germanic Basin provides unexpected implications for phylogeny. PLoS One 5: e11613.

613

614 Klein, N. (2012). Postcranial morphology and growth of the pachypleurosaur Anarosaurus

615 heterodontus (Sauropterygia) from the Lower Muschelkalk of Winterswijk, the Netherlands.

616 Palaeontologische Zeitschrift 86: 389-408.

617

618 Klein, N., Voeten, D. F., Lankamp, J., Bleeker, R., Sichelschmidt, O. J., Liebrand, M., ... \&

619 Sander, P. M. (2015). Postcranial material of Nothosaurus marchicus from the Lower

620 Muschelkalk (Anisian) of Winterswijk, The Netherlands, with remarks on swimming styles and

621 taphonomy. Paläontologische Zeitschrift, 89: 961-981.

622

623 Kooyman, G. L., Cherel, Y., Maho, Y. L., Croxall, J. P., Thorson, P. H., Ridoux, V., \& Kooyman, 624 C. A. (1992). Diving behavior and energetics during foraging cycles in king penguins. Ecological 625 Monographs, 62: 143-163.

626 
627 Kozłowski, J., Czarnołęski, M., François-Krassowska, A., Maciak, S., \& Pis, T. (2010). Cell size

628 is positively correlated between different tissues in passerine birds and amphibians, but not

629 necessarily in mammals. Biology Letters rsbl20100288.

630

631 Kozlowski, J., Konarzewski, M., \& Gawelczyk, A. T. (2003). Cell size as a link between

632 noncoding DNA and metabolic rate scaling. Proceedings of the National Academy of Sciences

633 100(24): 14080-14085.

634

635 Krahl, A., Klein, N., \& Sander, P.M. (2013). Evolutionary implications of the divergent long bone

636 histologies of Nothosaurus and Pistosaurus (Sauropterygia, Triassic). BMC Evolutionary Biology

637 13: 123.

638

639

Lay, P. A., \& Baldwin, J. (1999). What determines the size of teleost erythrocytes? Correlations

640 with oxygen transport and nuclear volume. Fish Physiology and Biochemistry 20: 31-35.

641

642

Legendre, L. J., Guénard, G., Botha-Brink, J., \& Cubo, J. (2016). Palaeohistological evidence 643 for ancestral high metabolic rate in archosaurs. Systematic Biology 65: 989-996.

644 MacNeill, A. C. (1975). Blood values for some captive cetaceans. The Canadian Veterinary Journal 16: 187-193.

646

Motani, R. 2009. The evolution of marine reptiles. Evolution: Education and Outreach 2:224648 235.

Neenan, J. M., Reich, T., Evers, S. W., Druckenmiller, P. S., Voeten, D. F., Choiniere, J. N., ... \& lifestyles. Current Biology, 27(24), 3852-3858.

652

Nicol, S. C., Melrose, W., \& Stahel, C. D. (1988). Haematology and metabolism of the blood of the little penguin, Eudyptula minor. Comparative biochemistry and Physiology. A, Comparative Physiology 89: 383-386.

656 marine plesiosaur (Reptilia, Sauropterygia). Science 333: 870-873. 
660 O'Keefe, F. R., P. M. Sander, T. Wintrich, \& S. Werning. 2019. Ontogeny of polycotylid long 661 bone microanatomy and histology. Integrative Organismal Biology 1: oby007.

662

663 Olivier, C., A. Houssaye, A., Jalil, N.-E., \& J. C. J (2017). First palaeohistological inference of 664 resting metabolic rate in an extinct synapsid, Moghreberia nmachouensis (Therapsida:

665 Anomodontia). Biological Journal of the Linnean Society 121: 409-419.

666

667

Pagel, M., \& Johnstone, R. A. (1992). Variation across species in the size of the nuclear 668 genome supports the junk-DNA explanation for the C-value paradox. Proceedings of the Royal Society of London B, 249:119-124.

670

Plet, C., Grice, K., Pagès, A., Verrall, M., Coolen, M. J., Ruebsam, W., .. \& Schwark, L. (2017). Palaeobiology of red and white blood cell-like structures, collagen and cholesterol in an ichthyosaur bone. Scientific Reports, 7: 13776.

674

Promislow, D. E. (1991). The evolution of mammalian blood parameters: patterns and their interpretation. Physiological Zoology, 64: 393-431.

677

R Core Team (2017). R: A Language and Environment for Statistical Computing. Vienna,

Renesto, S., \& Dalla Vecchia, F. M. (2018). Late Triassic marine reptiles. In: Tanner L.H. (Ed.):

682 The Late Triassic World: Earth in a Time of Transition. Springer Nature, Switzerland. 263-314. 683

Ridgway, S. H., Simpson, J. G., Patton, G. S., \& Gilmartin, W. G. (1970). Hematologic findings 685 in certain small cetaceans. Journal of the American Veterinary Medical Association 157: 566686 575.

687

Rieppel, O. (2000). Handbook of Paleoherpetology / Sauropterygia I.: Placodontia, Pachypleurosauria, Nothosauroidea, Pistosauroidea Part 12A: 4-6. Friedrich Pfeil Verlag, Munich.

691

692 Rothschild, B. M., \& Storrs, G. W. (2003). Decompression syndrome in plesiosaurs

693 (Sauropterygia: Reptilia). Journal of Vertebrate Paleontology 23:324-328. 
694

695 Saint Girons, M. C. (1970). Morphology of the circulating blood cells. In: Gans, C. \& Parsons, T.

696 S. (Eds.): Biology of the Reptilia Volume 3, Academic Press, London and New York. 73-91.

697

698 Sander, P. M. (1989). The pachypleurosaurids (Reptilia: Nothosauria) from the Middle Triassic

699 of Monte San Giorgio (Switzerland) with the description of a new species. Philosophical

700 Transactions of the Royal Society B 325: 561-666.

701

702

Sander, P. M. (1990). Skeletochronology in the small Triassic reptile Neusticosaurus. Annales

703 des Sciences Naturelles, Zoologie 11:213-217.

704

705

Schindelin, J., Arganda-Carreras, I., Frise, E., Kaynig, V., Longair, M., Pietzsch, T., Preibisch,

S., Rueden, C., Saalfeld, S., Schmid, B., Tinevez, J.-Y, White, D. J., Hartenstein, V., Eliceiri, K.,

Tomancak, P., \& Cardona, A. (2012). Fiji: an open-source platform for biological-image analysis.

708

Nature Methods 9: 676-682.

709

710

Starostová, Z., Kratochvíl, L., \& Flajšhans, M. (2008). Cell size does not always correspond to

711 genome size: phylogenetic analysis in geckos questions optimal DNA theories of genome size

712 evolution. Zoology, 111: 377-384.

713

714 Starostová, Z., Kratochvíl, L., \& Frynta, D. (2005). Dwarf and giant geckos from the cellular

715 perspective: the bigger the animal, the bigger its erythrocytes?. Functional Ecology 19: 744-749.

716

717 Sues, H. D. (1987). Postcranial skeleton of Pistosaurus and interrelationships of the

718 Sauropterygia (Diapsida). Zoological Journal of the Linnean Society, 90: 109-131.

719

720 Surmik, D., Rothschild, B. M., Dulski, M., \& Janiszewska, K. (2017). Two types of bone necrosis

721 in the Middle Triassic Pistosaurus longaevus bones: the results of integrated studies. Royal

722 Society Open Science, 4: 170204.

723

724 Venzlaff, W. (1911). Über Genesis und Morphologie der roten Blutkörperchen der Vögel. Archiv

725 für mikroskopische Anatomie 77: 377-432.

726 
727 Vinogradov, A. E. \& O. V. Anatskaya (2006). Genome size and metabolic intensity in tetrapods:

728 a tale of two lines. Proceedings of the Royal Society of London B: Biological Sciences 273: 2772932.

730

731 Wickham, L. L., Elsner, R., White, F. C., \& Cornell, L. H. (1989). Blood viscosity in phocid seals:

732 possible adaptations to diving. Journal of Comparative Physiology B, 159: 153-158.

733

734 Wintrich, T., Hayashi, S., Houssaye, A., Nakajima, Y., \& Sander, P.M. (2017). A Triassic

735 plesiosaurian skeleton and bone histology inform on evolution of a unique body plan and

736 survival of end-Triassic extinctions. Science Advances 3: e1701144.

737

738 Zhang, Q., Wen, W., Hu, S., Benton, M. J., Zhou, C., Xie, T., ... \& Liu, J. (2014). Nothosaur

739 foraging tracks from the Middle Triassic of southwestern China. Nature Communications 5 :

7403973. 


\section{Figure 1}

Cladogram of taxa included in the study with information on ecology.

Topology follows Rieppel (2000), Ketchum \& Benson (2010), and Wintrich et al. (2017). Color coding indicates the operational groups considered herein. The pink bar denotes basal eosauropterygian groups (Pachypleurosauridae, Nothosauroidea) from coastal and shallowwater habitats. The violet bar marks the paraphyletic Pistosauridae in which notable adaptations to offshore environments were acquired. The blue bar denotes the derived pelagic taxon Plesiosauria. Numbers indicate inclusive taxa: 1, Sauropterygia; 2 , Eosauropterygia; 3, Pachypleurosauridae; 4, Eusauropterygia; 5, Nothosauroidea; 6, Pistosauroidea; 7, Plesiosauria. Silhouettes by Kai R. Caspar. 
Coastal Pelagic
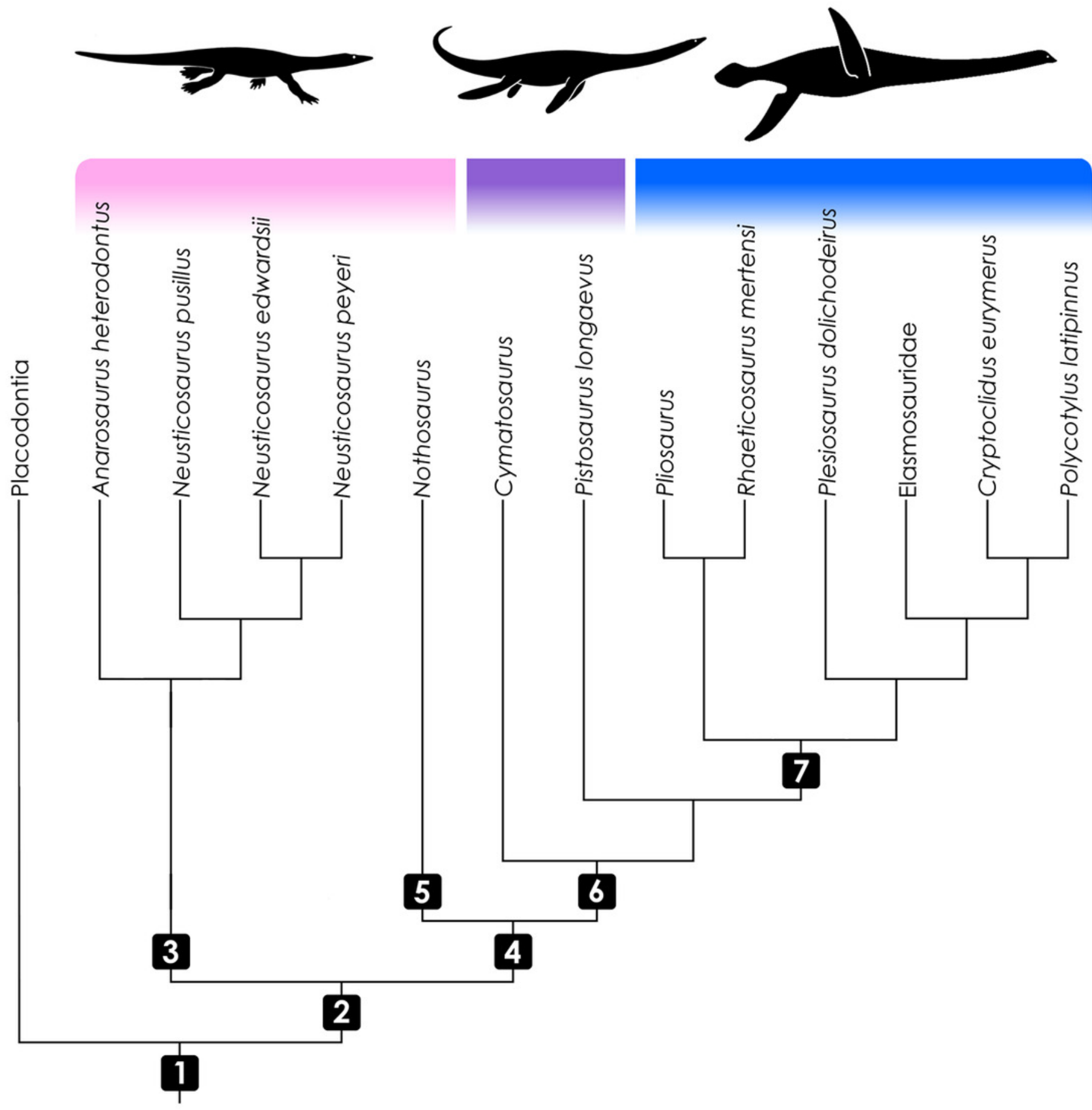
Figure 2

Bone histological thin-section of the femur of the plesiosaur Pliosaurus.

The width (smallest diameter, green bars) of longitudinal vascular canals and nodes in reticular canals found in the bone matrix were measured.

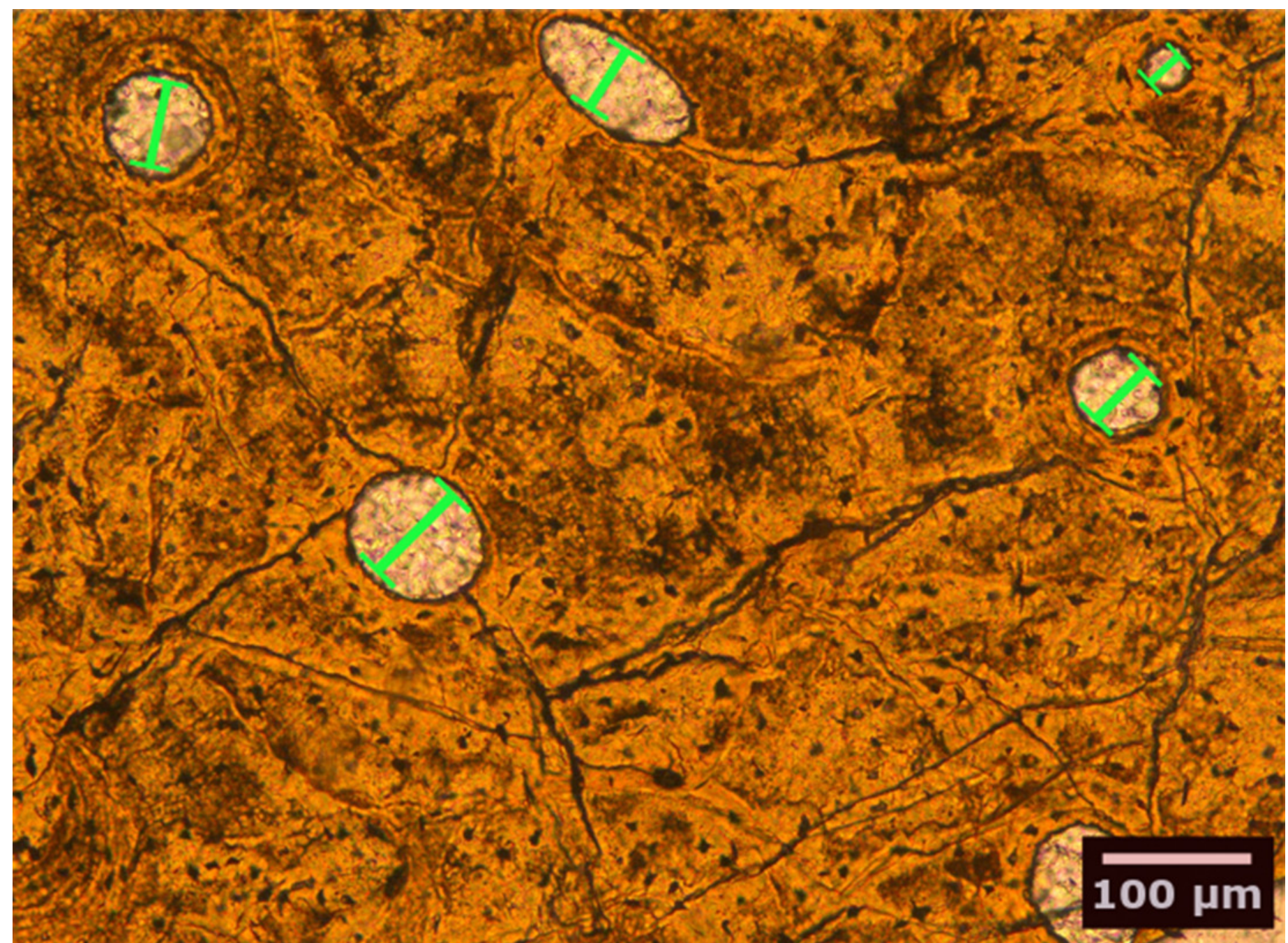




\section{Figure 3}

Estimated RBC area of 13 eosauropterygians, error bars indicating $95 \%$ confidence intervals.

Pachypleurosaurids and Nothosaurus (pink) have small cells, whereas pistosauroids ("Pistosauridae": purple; Plesiosauria: blue) have significantly larger RBCs. Numbers below error bars indicate frequency of propodial head subsidence diagnostic of avascular necrosis in eosauroperygian humeri suggestive of dysbaric stress experienced during deep dives. Data derive from Rothschild \& Storrs (2003) and Surmik et al. (2017) and are presented for the genus level, except for Elasmosauridae, since the sampled specimen is of ambiguous generic identity. Corresponding to the latter, data of all elasmosaurids listed in Rothschild \& Storrs (2003) are combinedly presented (excluding Colymbosaurus and Muraenosaurus).Silhouettes by Kai R. Caspar. 


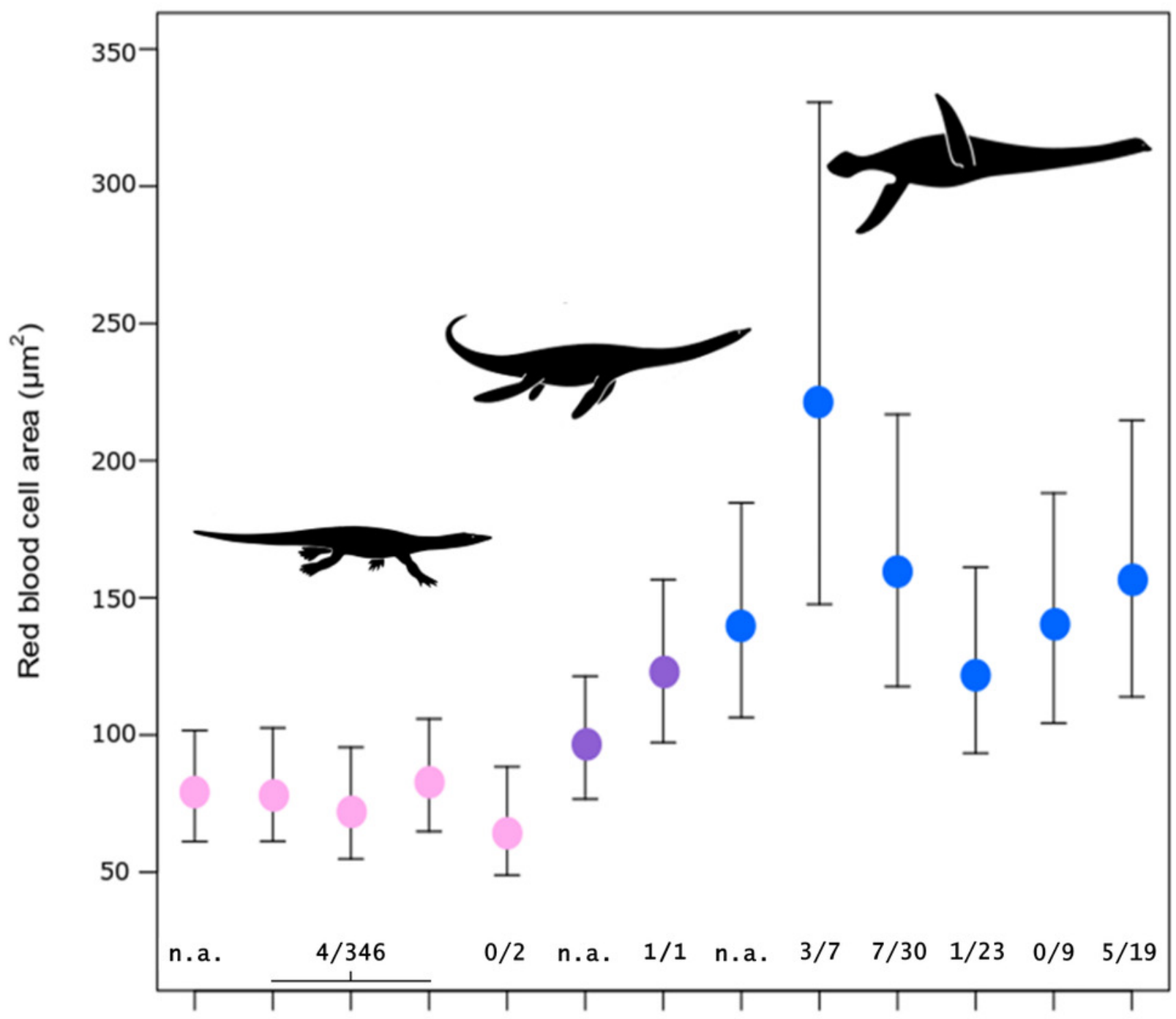

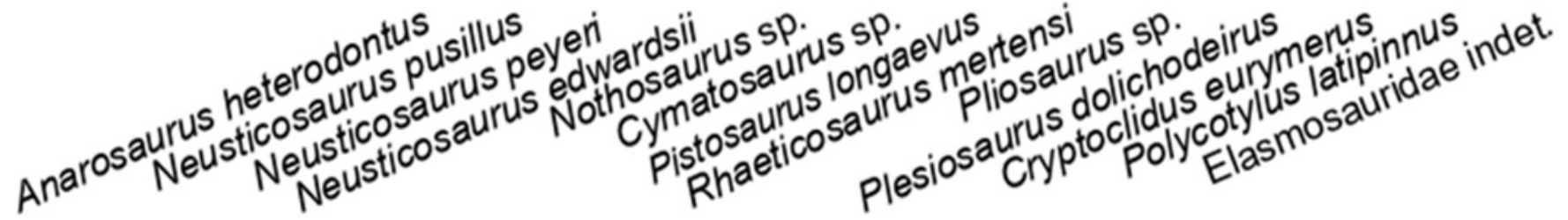


Figure 4

RBC area (a) and length (b) regressed against log body mass for 188 species of extant reptiles.

Crocodilia are plotted in blue, Lepidosauria in pink, and Testudines in green. The correlation is weak but statistically highly significant (a: adjusted $R^{2}=0.104, p$-value $=0.00017, d f=120$, b: adjusted $R^{2}=0.3373, p$-value $\left.<0.00001, d f=178\right)$.
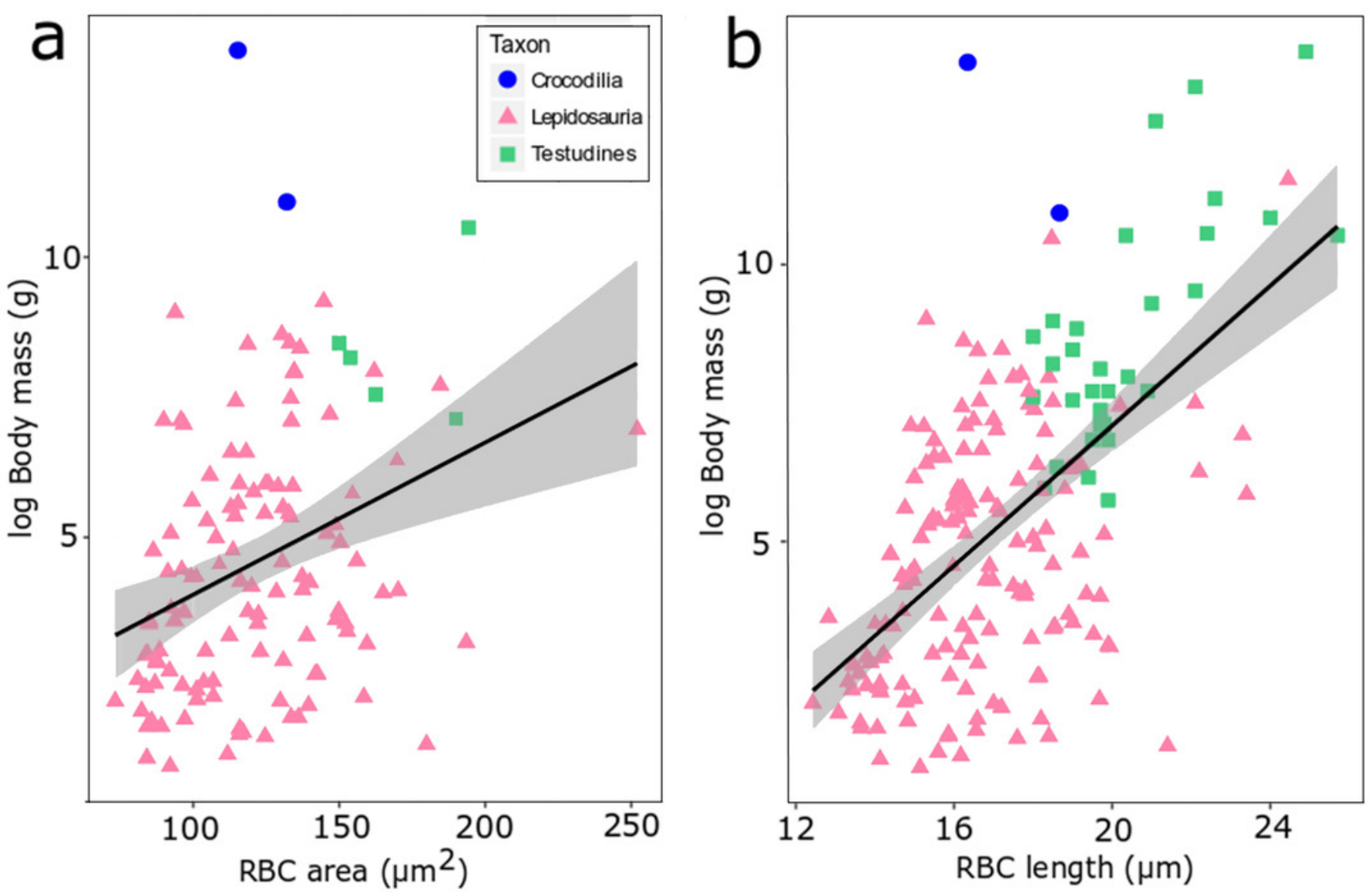
Figure 5

Comparison of RBC size expressed as volume in amniotes displaying varying aquatic adaptation.

Above: Mammalia; Middle: Aves; Below: Sauropterygia. All three clades show an increase in $\mathrm{RBC}$ volume from terrestrial or shallow-water taxa (pink) to more aquatic, deep-diving taxa (blue). Silhouettes by Kai R. Caspar.

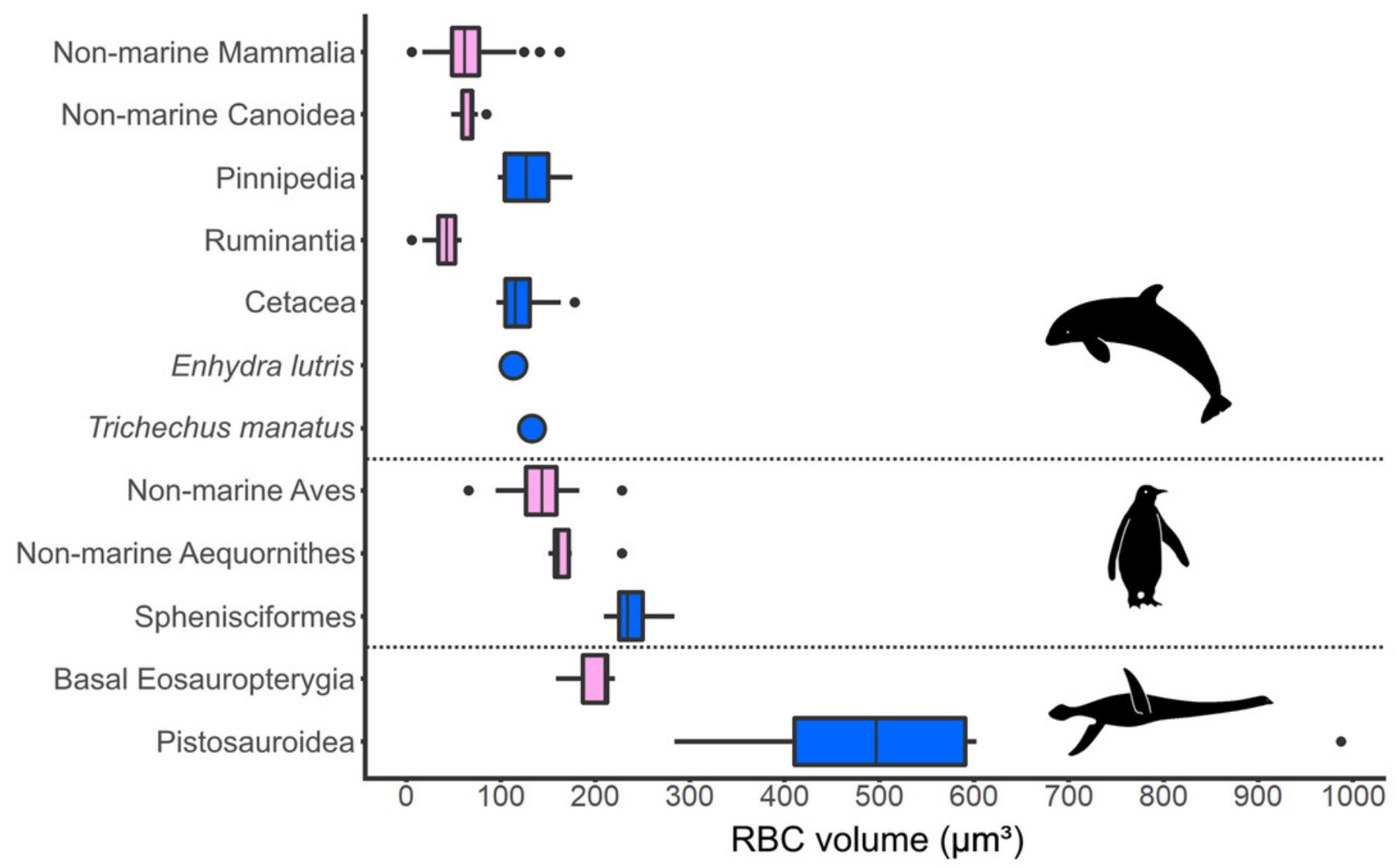




\section{Table $\mathbf{1}$ (on next page)}

List of eosauropterygian specimens studied.

Collection acronyms:IGWH, Institut für Geowissenschaften, University of Halle-Wittenberg, Halle, Germany; LWL-MFN, LWL- Museum für Naturkunde, Münster, Germany; NMNHL,National Museum of Natural History (NCB Naturalis), Leiden, The Netherlands; OMNH, Osaka Museum of Natural History, Osaka, Japan; PIMUZ, Paläontologisches Institut und Museum Universität Zürich, Zurich, Switzerland; SMNS, Staatliches Museum für Naturkunde, Stuttgart, Germany; STIPB, Steinmann Institute Paleontology Collection, University of Bonn, Bonn, Germany; LACM, Natural History Museum of Los Angeles County, Los Angeles, USA. 


\begin{tabular}{|c|c|c|c|c|c|}
\hline Species & Superordinate taxon & $\begin{array}{l}\text { Specimen } \\
\text { number }\end{array}$ & $\begin{array}{l}\text { Skeletal } \\
\text { element }\end{array}$ & $\begin{array}{l}\text { Geological } \\
\text { time }\end{array}$ & $\begin{array}{l}\text { Previously } \\
\text { studied by }\end{array}$ \\
\hline $\begin{array}{l}\text { Anarosaurus } \\
\text { heterodontus }\end{array}$ & Pachypleurosauridae & $\begin{array}{l}\text { NMNHL } \\
\text { Wijk. 06- } \\
38 \mathrm{fe}\end{array}$ & Femur & $\begin{array}{l}\text { Middle } \\
\text { Triassic }\end{array}$ & $\begin{array}{l}\text { Klein } \\
(2012), \\
\text { Fleischle et } \\
\text { al. (2018) }\end{array}$ \\
\hline $\begin{array}{l}\text { Neusticosaurus } \\
\text { edwardsii }\end{array}$ & Pachypleurosauridae & $\begin{array}{l}\text { PIMUZ } \\
\text { T3455 }\end{array}$ & Humerus & $\begin{array}{l}\text { Middle } \\
\text { Triassic }\end{array}$ & $\begin{array}{l}\text { Sander } \\
(1989, \\
1990), \\
\text { Fleischle et } \\
\text { al. (2018) }\end{array}$ \\
\hline $\begin{array}{l}\text { Neusticosaurus } \\
\text { peyeri }\end{array}$ & Pachypleurosauridae & $\begin{array}{l}\text { PIMUZ T } \\
4089\end{array}$ & Humerus & $\begin{array}{l}\text { Middle } \\
\text { Triassic }\end{array}$ & $\begin{array}{l}\text { Sander } \\
(1989, \\
1990)\end{array}$ \\
\hline $\begin{array}{l}\text { Neusticosaurus } \\
\text { pusillus }\end{array}$ & Pachypleurosauridae & $\begin{array}{l}\text { PIMUZ T } \\
3566\end{array}$ & Humerus & $\begin{array}{l}\text { Middle } \\
\text { Triassic }\end{array}$ & $\begin{array}{l}\text { Sander } \\
(1989, \\
1990)\end{array}$ \\
\hline Nothosaurus sp. & Nothosauroidea & IGWH 21 & Femur & $\begin{array}{l}\text { Middle } \\
\text { Triassic }\end{array}$ & $\begin{array}{l}\text { Klein } \\
(2010), \\
\text { Fleischle et } \\
\text { al. (2018) }\end{array}$ \\
\hline Cymatosaurus sp. & $\begin{array}{l}\text { Pistosauroidea indet. } \\
\text { (pistosaurid grade) }\end{array}$ & IGWH 6 & Humerus & $\begin{array}{l}\text { Middle } \\
\text { Triassic }\end{array}$ & $\begin{array}{l}\text { Klein } \\
(2010)\end{array}$ \\
\hline $\begin{array}{l}\text { Pistosaurus } \\
\text { longaevus }\end{array}$ & Pistosauridae & $\begin{array}{l}\text { SMNS } \\
84825\end{array}$ & Humerus & $\begin{array}{l}\text { Middle } \\
\text { Triassic }\end{array}$ & $\begin{array}{l}\text { Krahl et al. } \\
(2013), \\
\text { Fleischle et } \\
\text { al. (2018) }\end{array}$ \\
\hline $\begin{array}{l}\text { Cryptoclidus } \\
\text { eurymerus }\end{array}$ & Plesiosauria: Cryptoclididae & $\begin{array}{l}\text { STIPB R } \\
324\end{array}$ & Femur & $\begin{array}{l}\text { Middle } \\
\text { Jurassic }\end{array}$ & $\begin{array}{l}\text { Wintrich et } \\
\text { al. (2017), } \\
\text { Fleischle et } \\
\text { al. (2018) }\end{array}$ \\
\hline $\begin{array}{l}\text { Elasmosauridae } \\
\text { indet. }\end{array}$ & Plesiosauria: Elasmosauridae & $\begin{array}{l}\text { OMNH } \\
\text { MV } 85\end{array}$ & Humerus & $\begin{array}{l}\text { Late } \\
\text { Cretaceous }\end{array}$ & $\begin{array}{l}\text { Wintrich et } \\
\text { al. (2017), } \\
\text { Fleischle et } \\
\text { al. (2018) }\end{array}$ \\
\hline
\end{tabular}




\begin{tabular}{|c|c|c|c|c|c|}
\hline $\begin{array}{l}\text { Plesiosaurus } \\
\text { dolichodeirus }\end{array}$ & Plesiosauria: Plesiosauridae & STIPB R90 & Femur & $\begin{array}{l}\text { Early } \\
\text { Jurassic }\end{array}$ & $\begin{array}{l}\text { Wintrich et } \\
\text { al. (2017), } \\
\text { Fleischle et } \\
\text { al. (2018) }\end{array}$ \\
\hline Pliosaurus sp. & Plesiosauria: Pliosauridae & $\begin{array}{l}\text { SMNS } \\
96896\end{array}$ & Femur & $\begin{array}{l}\text { Middle } \\
\text { Jurassic }\end{array}$ & \\
\hline $\begin{array}{l}\text { Polycotylus } \\
\text { latipinnus }\end{array}$ & Plesiosauria: Polycotylidae & $\begin{array}{l}\text { LACM } \\
\text { 129639A } \\
\text { ("Mom") }\end{array}$ & Femur & $\begin{array}{l}\text { Late } \\
\text { Cretaceous }\end{array}$ & $\begin{array}{l}\text { O'Keefe et } \\
\text { al. (2019) }\end{array}$ \\
\hline $\begin{array}{l}\text { Rhaeticosaurus } \\
\text { mertensi }\end{array}$ & Plesiosauria: Pliosauridae & $\begin{array}{l}\text { LWL MfN } \\
\text { P } 64047 \\
\text { section } \\
\text { PM3 }\end{array}$ & Femur & Late Triassic & $\begin{array}{l}\text { Wintrich et } \\
\text { al. (2017), } \\
\text { Fleischle et } \\
\text { al. (2018) }\end{array}$ \\
\hline
\end{tabular}

2

3

4 


\section{Table 2 (on next page)}

Estimates of different RBC size proxies in Eosauropterygia. Area and width were estimated based on the Huttenlocker \& Farmer (2017) data set for extant species. Volumes and lengths were calculated from area and width.

Area and width were estimated based on the Huttenlocker \& Farmer (2017) data set for extant species. Volumes and lengths were calculated from area and width. 


\begin{tabular}{|llllll|}
\hline Species & Higher taxon & $\begin{array}{l}\text { Area } \\
\left(\mu \mathrm{m}^{2}\right)\end{array}$ & $\begin{array}{l}\text { Width } \\
(\mu \mathrm{m})\end{array}$ & $\begin{array}{l}\text { Length } \\
(\mu \mathrm{m})\end{array}$ & $\begin{array}{l}\text { Volume } \\
\left(\mu \mathrm{m}^{3}\right)\end{array}$ \\
\hline Anarosaurus heterodontus & Pachypleurosauridae & 78.8 & 8.0 & 12.54 & 210.1 \\
\hline Neusticosaurus edwardsii & Pachypleurosauridae & 82.8 & 8.2 & 12.86 & 220.9 \\
\hline Neusticosaurus peyeri & Pachypleurosauridae & 72.4 & 7.7 & 11.97 & 186.7 \\
\hline Neusticosaurus pusillus & Pachypleurosauridae & 79.3 & 8.0 & 12.62 & 211.5 \\
\hline Nothosaurus sp. & Nothosauroidea & 65.75 & 7.3 & 11.47 & 159.4 \\
\hline Cymatosaurus sp. & "Pistosauridae" & 96.5 & 8.8 & 13.97 & 284.4 \\
\hline Pistosaurus longaevus & "Pistosauridae" & 122.7 & 10.0 & 15.62 & 405.7 \\
\hline Elasmosauridae indet. & Plesiosauria & 156.4 & 11.3 & 17.6 & 585.8 \\
\hline Cryptoclidus eurymerus & Plesiosauria & 123.4 & 10.0 & 15.7 & 411.6 \\
\hline Plesiosaurus dolichodeirus & Plesiosauria & 159.8 & 11.4 & 17.9 & 602.7 \\
\hline Pliosaurus sp. & & & & & 987.2 \\
\hline Polycotylus latipinnus & Plesiosauria & 220.9 & 13.4 & 21.0 & 498.4 \\
\hline Rhaeticosaurus mertensi & Plesiosauria & 140.2 & 10.7 & 16.7 & 494.6 \\
\hline
\end{tabular}

2

3

4 